A. L. Roberts ; Chemical Engineering, directed by the Brotherton professor - a newly established chair ; Metallurgy, directed by the reader in metallurgy, Dr. N. J. Petch.

\section{The European Coal and Steel Community}

The Broadsheet issued by Political and Economic Planning on the "European Coal and Steel Community" (No. 389. November 21, 1955) is of some current interest in view of the possibility that institutions which have served the Community well so far may be taken as a model for the development of the peaceful uses of atomic energy. The Treaty establishing the Community was signed on April 18, 1951, and the Broadsheet briefly describes the evolution of what is the only truly supra-national organization in Western Europe which seeks to unify markets and control basic resources by eliminating six obstacles : customs duties and quantitative restrictions on coal and steel movements between the member countries; discriminatory transport rates; price discrimination for domestic and export sales within the Community area; cartels and agreements on restraint of trade; government subsidies; and government control of prices. The organization for achieving these objectives consists of an executive body, the High Authority, to establish and maintain the common market and answerable to the Common Assembly, a Consultative Committee, a Council of Ministers and a Court of Justice. The development of the Community has already passed through what may be called the opinion-forming stage and has now entered a second phase of long-term policies, European rather than national in character. As an economic experiment, the Community has been a success so far as the six countries are concerned, and Britain set up in July 1952 a joint committee for the exchange of full information of common interest and has maintained cordial relations with the High Authority ever since. What happens next in the Community depends on political rather than economic policies, and the Broadsheet points out that the view is widely held that progress is most likely in the integration of the production of atomic energy but that rejection of the European Defence Community has left it high and dry as the sole trophy of the federalist movement.

\section{U.S. National Science Foundation : Senior Post- doctoral Fellowships}

Applications are invited for the second group of senior postdoctoral fellowships to be awarded by the U.S. National Science Foundation during the current calendar year. These will be awarded in mathematical, physical, medical, biological, engineering and other sciences, including anthropology, psychology (other than clinical), geography, certain interdisciplinary fields, and areas of convergence between the natural and social sciences. To be eligible for these awards, candidates must be citizens of the United States. Annual stipends of 2,00010,000 dollars, adjusted to match as closely as feasible the regular salaries of the award recipients, may be applied toward study or research in an accredited non-profit institution of higher learning in the United States or abroad. A limited allowance to aid in defraying costs of travel for a Fellow and his dependants will also be available. Further details can be obtained from the Division of Scientific Personnel and Education, National Science Foundation, Washington 25, D.C.

\section{Review of Czekoslovak Medicine}

ThE quarterly journal Review of Czekoslovak Medicine (1, No. 1 ; 1955. Praha : Státní Zdravotnické Nakladatelství (Sokolská tr. 31)), which is printed in English only, fulfils, to quote the words of its introductory article by B. Spaček, vice-chairman of the Scientific Council of the Czechoslovak Ministry of Health, "a natural and earnest desire of all Czekoslovak medical scientists to bring their work before a truly international audience. Czekoslovak physicians have regretted that, no matter how significant or valuable their work, it has for the most part, because of language difficulties, been insufficiently known in foreign countries ..." and "too often ... the priority of outstanding work by Czekoslovak investigators" has been "denied, incorrectly, by scientists of other nations. ..." This introductory article then mentions Czech investigators whose work is insufficiently known outside their own country and explains that "Czekoslovak science passed through its most arduous trials during the Hitler occupation", when its universities were closed and its workers were persecuted. "Only with the establishment of our People's Democracy, which is building socialism on a scientific basis, is a foresighted policy being pursued ..." and "publishing facilities ... have been enlarged .. ." until nowadays "fifty medical and health journals are published". The article concludes with an appeal for a friendly reception of this new journal, which is "an expression of our deep conviction that mutual understanding can bring about both lasting peace between the nations and the prosperity of all mankind".

The rest of the first issue of the journal contains scientific contributions, with annotations, abstracts and reviews. The leading article, by F. Burian, describes the development of plastic surgery in Czechoslovakia. Other contributions are: research on the pathophysiology and some symptoms of hysteria (J. Cernácek); sodium citrate-one of the main causes of cardiac overloading and failure in rapid blood transfusion (P. Firt and L. Hejhal), and ascorbigen - the bound form of ascorbic acid (Z). Procházka). An annotation by K. Hübschmann deals with the venereal disease campaign in Czechoslovakia, and another, by F. Démant and T. Prehop, with acute infectious hepatitis. A note by the editor points out that references appended to the individual papers quote only the work of Soviet, Czech or Slovak authors, this being an effort to economize space and to acquaint English-speaking readers with work "less easily accessible to them"; but if it "should prove desirable to quote fully all work cited", an effort will be made to do this in future issues. The subtitle of the journal is "Journal of the Czekoslovak J. E. Purkyner Medical Association" and this commemorates one of the world's very great histologists and physiologists.

\section{British Hat and Allied Feltmakers Research Asso. ciation : Report for 1955}

THE eighth annual report of the Director of Research of the British Hat and Allied Feltmakers Research Association, covering the year ended August 1955 (pp. 23; from the Association, Manchester, 1955), notes that, besides continuing work on the technology of carrotting of fur, a better picture of the initial reactions in the carrotting process appears to be obtained by studying the absorption of mercury from solutions of mercuric 